\title{
A Comparative Kinetic Study on the Efficacious Permanganate Oxidation of Fluorenes in Perchloric and Sulfuric Acid Media
}

\author{
Rabab S. Jassas ${ }^{1}$, Ahmed Fawzy ${ }^{1,2 *}$, Rami J. Obied', Mohammed A. S. Abourehab ${ }^{3,4}$, \\ Saleh A. Ahmed ${ }^{1,2 *}$ \\ ${ }^{1}$ Chemistry Department, Faculty of Applied Science, Umm Al-Qura University, Makkah, Saudi Arabia \\ ${ }^{2}$ Chemistry Department, Faculty of Science, Assiut University, Assiut, Egypt \\ ${ }^{3}$ Department of Pharmaceutics, Faculty of Pharmacy, Umm Al-Qura University, Makkah, Saudi Arabia \\ ${ }^{4}$ Department of Pharmaceutics and Industrial Pharmacy, Faculty of Pharmacy, Minia University, Minia, Egypt \\ Email: *afsaad13@yahoo.com, *saleh_63@hotmail.com
}

How to cite this paper: Jassas, R.S., Fawzy, A., Obied, R.J., Abourehab, M.A.S. and Ahmed, S.A. (2017) A Comparative Kinetic Study on the Efficacious Permanganate Oxidation of Fluorenes in Perchloric and Sulfuric Acid Media. Open Journal of Physical Chemistry, 7, 35-49.

https://doi.org/10.4236/ojpc.2017.72004

Received: January 15, 2017

Accepted: May 8, 2017

Published: May 11, 2017

Copyright $\odot 2017$ by authors and Scientific Research Publishing Inc. This work is licensed under the Creative Commons Attribution International License (CC BY 4.0).

http://creativecommons.org/licenses/by/4.0/

\begin{abstract}
Oxidation kinetics of fluorene (Fl) and its halogenated derivatives, namely, 2,7-dichlorofluorene (Fl-Cl), 2,7-dibromofluorene (Fl-Br) and 2,7-diiodofluorene (Fl-I), by permanganate ion in both perchloric and sulfuric acid media have been investigated using conventional spectrophotometric technique. In both acidic media, the reactions manifested first order kineticsin [permanganate] and less than unit order each in [reductants] and [acid]. Increasing ionic strength had no effect on the oxidation rates. Oxidation rates of fluorenes in perchloric acid were higher than those in sulfuric acid and the order of the oxidation rates was: $\mathrm{Fl}>\mathrm{Fl}-\mathrm{I}>\mathrm{Fl}-\mathrm{Br}>\mathrm{Fl}-\mathrm{Cl}$. Final oxidation products were identified by GC/MS and FT-IR analyses in all cases as $9 \mathrm{H}$-fluorenone derivatives. Reaction constants as well as activation parameters of the second order rate constants were also evaluated.
\end{abstract}

\section{Keywords}

Oxidation, Kinetics, Mechanism, Fluorenes, Permanganate

\section{Introduction}

Fluorenes (FLs) are an exclusive family of aromatic hydrocarbons. They are amongst products from the burning of gasoline [1] [2]. Fluorene moiety is frequently engaged in the growing of a variety of visual devices with dormant applications in some electronic devices such as solar cells [3], polymer based lightemitting diodes [4] [5] and electroemitting resources [6]. Furthermore, fluorene founded systems enjoy solitary photophysical properties since they exposed 
pronounced high fluorescent quantum yield, countless optical nonlinear properties, photo-stability, and outstanding hole-transporting possessions [7] [8]. For these inserting and multi-addressable properties, fluorenes have been used extensively as focused constituents for organic light-emitting diodes, dye-sensitized solar cells, photosensitizers, emission microscopy [9] [10]. Furthermore, fluorene and its substituted derivatives are shown some effective and noticeable precursors for the synthesis of the sounding and promising photochromic di and tetrahydroindolizines [11] [12] [13].

Potassium permanganate is considered as the most powerful multi-electron oxidant employed in the kinetic studies of oxidation of various compounds in different media [14]-[22]. The mechanism of oxidation by this eco-friendly oxidant depends not only on the reductant but also on the reaction medium. Throughout permanganate oxidation, manganese (VII) species in permanganate is reduced to various oxidation states in different media [23]-[28]. However, no work has been reported on the kinetics and mechanism of oxidation of fluorene or its derivatives as well. In view of the above arguments, we tend to investigate the kinetics and mechanism of oxidation of fluorine and its halogenated derivatives with permanganate ion in both perchloric and sulfuric acids media in order to establish the optimum conditions affecting such oxidations and to elucidate a plausible oxidation mechanism.

\section{Experimental}

\subsection{Materials}

Fluorene and its derivatives, 2,7-dichloroflourene, 2,7-dibromoflourene and 2,7diiodoflourene were synthesized as reported [29] [30] and the synthesized fluorene derivatives were characterized by both spectroscopic and analytical tools. For example, the $1 \mathrm{H} \mathrm{NMR}\left(400 \mathrm{MHz}, \mathrm{CDCl}_{3}\right.$ ) spectrum of 2,7-dibrom-fluorene showed the flowing signals $(\delta=7.66(\mathrm{~s}, 2 \mathrm{H}, 1,8-\mathrm{CH}$-arom.), 7.55-7.59 (dd, $\mathrm{J}=$ 7.6, $1.5 \mathrm{~Hz}, 2 \mathrm{H}, 3.6-\mathrm{CH}$-arom.), 7.50-7.52 (dd, J = 7.6, $2.4 \mathrm{~Hz}, 2 \mathrm{H}, 4,5-\mathrm{CH}$-arom. A fresh solution of permanganate was prepared and was standardized as reported earlier [31] [32]. All other chemicals were of Aldrich grade.

\subsection{Kinetic Measurements}

Kinetic runs were carried out under pseudo-first order conditions where the concentration of fluorine derivatives, $[\mathrm{S}] \gg$ [permanganate]. The reactions temperature $\left(25^{\circ} \mathrm{C}\right)$ was controlled within $\pm 0.1^{\circ} \mathrm{C}$ and the ionic strength was adjusted to $0.5 \mathrm{~mol} \cdot \mathrm{dm}^{-3}$. Kinetics of the oxidation reactions were followed spectrophotometrically within the UV-Vis spectral range by recording the disappearance of permanganate absorbance with time at $\lambda=526 \mathrm{~nm}$. These measurements were performed on a thermostatted Shimadzu UV-VIS-NIR-3600 double-beam spectrophotometer. Fluorene derivatives were confirmed by both spectroscopic and analytical tools. NMR was recorded on a Bruker Advance 400 $\mathrm{MHz}$ and GC-Mass spectra were recorded on a Shimadzu GCMS-QP1000 EX mass spectrometer at $70 \mathrm{eV}$. The observed-first order rate constants $\left(k_{\mathrm{obs}}\right)$ were 
calculated as slopes of the plots of $\ln$ (absorbance) versus time plots, which were straight for about $75 \%$ of the oxidation reactions and the such rate constants were reproducible to within $3 \%-4 \%$.

\section{Results and Discussion}

\subsection{Stoichiometry and Product Analysis}

Various sets of the reactions mixtures containing different ratios of permanganate to fluorine derivatives were mixed at $\left[\mathrm{H}^{+}\right]=0.3$ and $I=0.5 \mathrm{~mol} \cdot \mathrm{dm}^{-3}$ for about 24 hours. Estimation of the remaining permanganate indicate that stoichiometry of the reactions was 5:4 (fluorine:permanganate) as illustrated by the following equation.<smiles>[Y4]c1ccc2c(c1)C(=O)c1cc([X])ccc1-2</smiles>

This stoichiometric equation is consistent with products characterization (Head-space GC/MS revealed $\left[\mathrm{M}^{+}, 100 \%\right]$ at 180 related to the $9 \mathrm{H}$-fluoren-9-one $\left[\mathrm{M}^{+}, 100 \%\right]$ at 249 related to the 2,7 -dichloro-9H-fluoren-9-one, $\left[\mathrm{M}^{+}, 100 \%\right]$ at 338 related to the 2,7-dibromo-9H-fluoren-9-one and $\left[\mathrm{M}^{+}, 100 \%\right]$ at 432 related to the 2,7-diiodo-9H-fluoren-9-one. The mass spectrometry fragmentation pattern for 2,7-dichloro-9H-fluoren-9-one (as an example) showed the following signals: $\mathrm{m} / \mathrm{z}$ : 247.98 (100.0\%), 249.98 (64.1\%), 248.98 (14.1\%), 251.97 (10.2\%), 250.98 (9.1\%), 252.98 (1.5\%). Furthermore, FT-IR spectra for both 2,7-dichloro$9 \mathrm{H}$-fluorene (Fl-Cl) and its oxidation product 2,7-dichloro-9H-fluoren-9-one (as an example) are shown in Figure 1. The product 2,7-dichloro-9H-fluoren-9-one

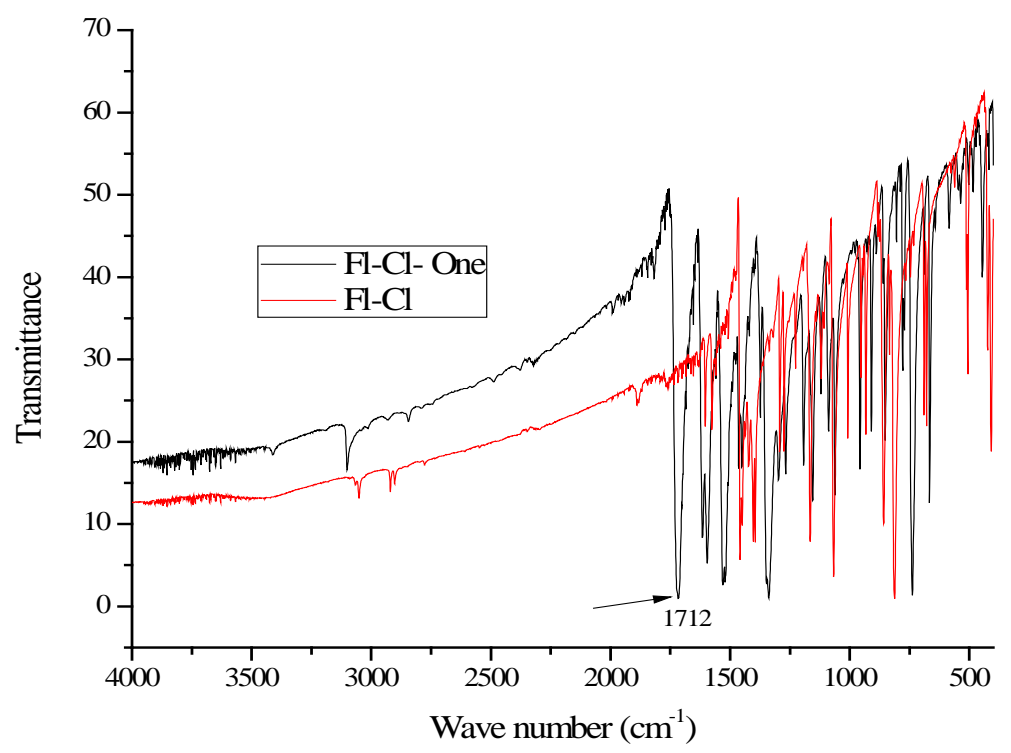

Figure 1. FT-IRs spectra of 2,7-dichloro-9H-fluorene (red line) and the oxidized product 2,7-dichloro-9H-fluoren-9-one (black line). 
showed a very strong signal at $1712 \mathrm{~cm}^{-1}$ related to the $(\mathrm{C}=\mathrm{O})$ group which is absent in the 2,7-dichloro-9H-fluorene (Fl-Cl). In addition, the finger prints of the product were different from that of the corresponding substrate.

\subsection{Spectral Changes}

Figure 2(a) and Figure 2(b) shows the spectral changes throughout oxidations of fluorene by potassium permanganate in: a) perchloric, and b) sulfuric acid media (as an example). The figure showed gradual disappearance of permanganate band at $\lambda=526 \mathrm{~nm}$.

\subsection{Order of Reactions}

The orders of the oxidation reactions regarding to the reactants concentrations have been evaluated from the plots of $\log k_{\mathrm{obs}}$ versus $\log$ (conc.).

The order with respect to $\left[\mathrm{MnO}_{4}^{-}\right]$was investigated by changing its concentration from $1.0 \times 10^{-4}$ to $8.0 \times 10^{-4} \mathrm{~mol} \cdot \mathrm{dm}^{-3}$ at constant concentrations of other reactants. The order was found to be unity as first order plots were linear for

Table 1. Effect of variation of $\left[\mathrm{MnO}_{4}^{-}\right],[\mathrm{S}],\left[\mathrm{H}^{+}\right]$and $I$ on the observed first order rate constants $\left(k_{\mathrm{obs}}\right)$ in the oxidations of fluorene and its derivatives by permanganate ion in perchloric and sulfuric acids media at $25^{\circ} \mathrm{C}$.

\begin{tabular}{|c|c|c|c|c|c|c|c|c|c|c|c|}
\hline \multirow{3}{*}{$\begin{array}{c}10^{4}\left[\mathrm{MnO}_{4}^{-}\right] \\
\left(\mathrm{mol} \cdot \mathrm{dm}^{-3}\right)\end{array}$} & \multirow{3}{*}{$\begin{array}{c}10^{3}[\mathrm{~S}] \\
\left(\mathrm{mol} \cdot \mathrm{dm}^{-3}\right)\end{array}$} & \multirow{3}{*}{$\begin{array}{c}10^{2}\left[\mathrm{H}^{+}\right] \\
\left(\mathrm{mol} \cdot \mathrm{dm}^{-3}\right)\end{array}$} & \multirow{3}{*}{$\begin{array}{c}I \\
\left(\mathrm{~mol} \cdot \mathrm{dm}^{-3}\right)\end{array}$} & \multicolumn{8}{|c|}{$10^{5} k_{\text {obs }}\left(\mathrm{s}^{-1}\right)$} \\
\hline & & & & \multicolumn{4}{|c|}{ Perchloric acid } & \multicolumn{4}{|c|}{ Sulfuric acid } \\
\hline & & & & $\mathrm{Fl}$ & $\mathrm{Fl}-\mathrm{Cl}$ & Fl-Br & Fl-I & Fl & $\mathrm{Fl}-\mathrm{Cl}$ & Fl-Br & Fl-I \\
\hline 1.0 & 5.0 & 0.2 & 0.5 & 166.2 & 101.2 & 113.9 & 129.2 & 139.3 & 86.2 & 98.7 & 121.0 \\
\hline 2.0 & 5.0 & 0.2 & 0.5 & 165.7 & 98.3 & 117.4 & 135.6 & 135.7 & 87.9 & 97.8 & 115.2 \\
\hline 4.0 & 5.0 & 0.2 & 0.5 & 168.1 & 99.7 & 116.9 & 133.1 & 137.2 & 88.0 & 99.3 & 117.6 \\
\hline 6.0 & 5.0 & 0.2 & 0.5 & 172.1 & 100.7 & 115.2 & 132.2 & 141.1 & 85.9 & 103.2 & 118.1 \\
\hline 8.0 & 5.0 & 0.2 & 0.5 & 169.3 & 97.3 & 118.2 & 134.1 & 133.2 & 89.2 & 98.2 & 116.2 \\
\hline 4.0 & 1.0 & 0.2 & 0.5 & 79.8 & 39.2 & 48.4 & 59.7 & 50.1 & 32.8 & 36.3 & 41.7 \\
\hline 4.0 & 3.0 & 0.2 & 0.5 & 127.3 & 74.1 & 85.3 & 97.2 & 96.9 & 62.3 & 73.1 & 87.2 \\
\hline 4.0 & 5.0 & 0.2 & 0.5 & 168.1 & 99.7 & 116.9 & 133.1 & 137.2 & 88.0 & 99.3 & 117.6 \\
\hline 4.0 & 7.0 & 0.2 & 0.5 & 201.0 & 120.2 & 139.9 & 161.0 & 175.9 & 108.7 & 125 & 145.0 \\
\hline 4.0 & 9.0 & 0.2 & 0.5 & 232.4 & 141.5 & 166.2 & 189.8 & 204.9 & 128.2 & 152 & 175.4 \\
\hline 4.0 & 5.0 & 0.1 & 0.5 & 105.3 & 63.1 & 70.3 & 81.9 & 81.6 & 48.5 & 55.8 & 68.9 \\
\hline 4.0 & 5.0 & 0.2 & 0.5 & 139.9 & 84.7 & 95.3 & 111.2 & 112.0 & 71.8 & 83.3 & 95.2 \\
\hline 4.0 & 5.0 & 0.3 & 0.5 & 168.1 & 99.7 & 116.9 & 133.1 & 137.2 & 88.0 & 99.3 & 117.6 \\
\hline 4.0 & 5.0 & 0.4 & 0.5 & 195.3 & 115.0 & 134.9 & 158.0 & 159.3 & 102.1 & 115.8 & 134.3 \\
\hline 4.0 & 5.0 & 0.5 & 0.5 & 216.0 & 124.9 & 148.0 & 181.0 & 185.0 & 113.9 & 132.2 & 155.0 \\
\hline 4.0 & 5.0 & 0.2 & 0.5 & 168.1 & 99.7 & 116.9 & 133.1 & 137.2 & 88.0 & 99.3 & 117.6 \\
\hline 4.0 & 5.0 & 0.2 & 0.6 & 169.7 & 98.3 & 119.4 & 135.6 & 135.7 & 87.9 & 101.2 & 115.2 \\
\hline 4.0 & 5.0 & 0.2 & 0.7 & 171.2 & 102.7 & 116.9 & 134.4 & 139.2 & 91.2 & 99.3 & 121.6 \\
\hline 4.0 & 5.0 & 0.2 & 0.8 & 172.1 & 105.7 & 121.2 & 137.2 & 141.1 & 85.9 & 103.2 & 118.1 \\
\hline 4.0 & 5.0 & 0.2 & 0.9 & 167.3 & 97.4 & 118.1 & 134.1 & 139.2 & 87.2 & 104.3 & 122.2 \\
\hline
\end{tabular}

Ex Experimental error $\pm 3 \%$. 


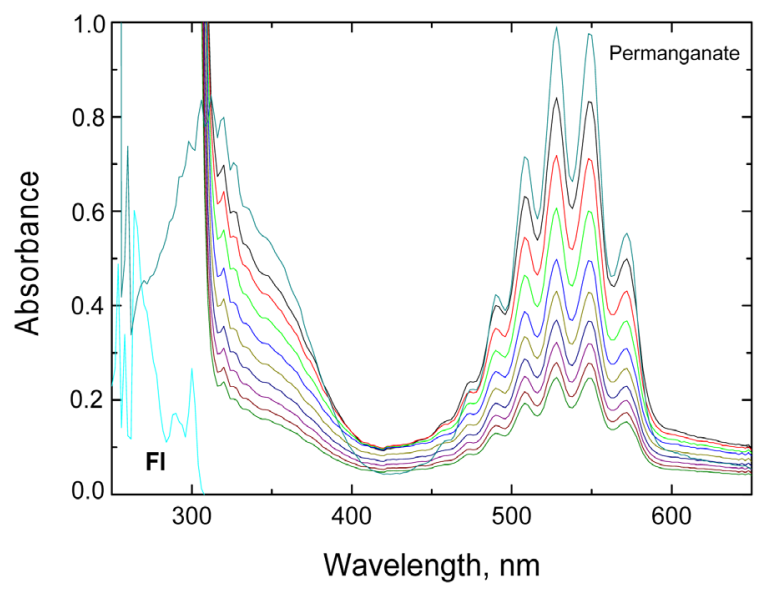

(a)

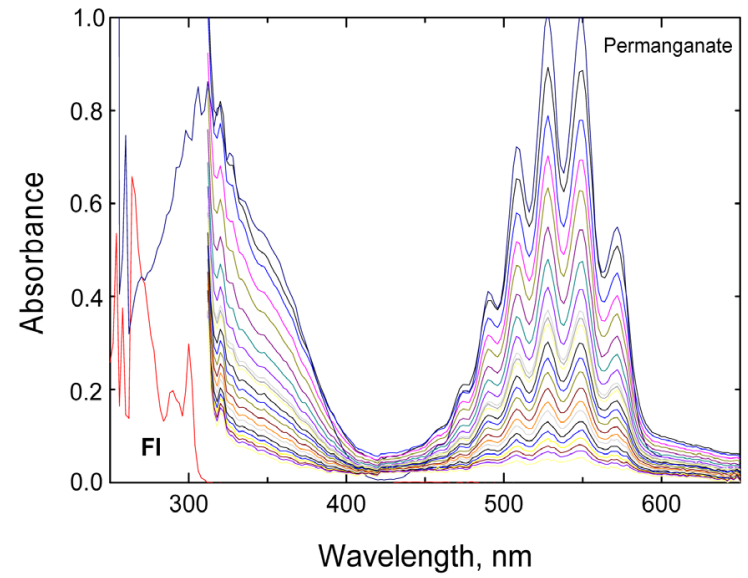

(b)

Figure 2. Spectral changes during the oxidations of fluorene by permanganateion in: (a) perchloric, and (b) sulfuric acid media. $[\mathrm{S}]=5.0 \times 10^{-3},\left[\mathrm{MnO}_{4}^{-}\right]=4.0 \times 10^{-4},\left[\mathrm{H}^{+}\right]=$ 0.3 and $I=0.5 \mathrm{~mol} \cdot \mathrm{dm}^{-3}$ at $25^{\circ} \mathrm{C}$. Scanning time $=1.0 \mathrm{~min}$.

about $75 \%$ of the oxidation reactions. Furthermore, the non-variation of the values of $k_{\text {obs }}$ at different initial $\left[\mathrm{MnO}_{4}^{-}\right]$, as listed in Table 1 , confirmed the unit order dependence of the reactions in $\left[\mathrm{MnO}_{4}^{-}\right]$.

The values of $k_{\mathrm{obs}}$ were measured at various concentrations of fluorine derivatives (S) at fixed other reactants concentrations. The values of $k_{\mathrm{obs}}$ were found to increase with increase [S] as listed in Table 1 . The plots of $k_{\mathrm{obs}}$ versus [S] in both acids were linear with positive intercepts suggesting that the orders of the reactions regarding to $[\mathrm{S}]$ were less than unity as shown in Figure 3.

The orders of reactions with respect to $\left[\mathrm{H}^{+}\right]$were investigated by measuring the oxidation rates at various $\left[\mathrm{H}^{+}\right]\left(0.1-0.5 \mathrm{~mol} \cdot \mathrm{dm}^{-3}\right)$ and at fixed other variables. The rate constants were increased as $\left[\mathrm{H}^{+}\right]$increased in both acidic media as listed in Table 1 with less than unit order dependences as the plots of $k_{\text {obs }}$ versus $\left[\mathrm{H}^{+}\right]$, Figure 4.

\subsection{Effect of Ionic Strength}

At constant concentrations of the reactants and with other conditions constant, 


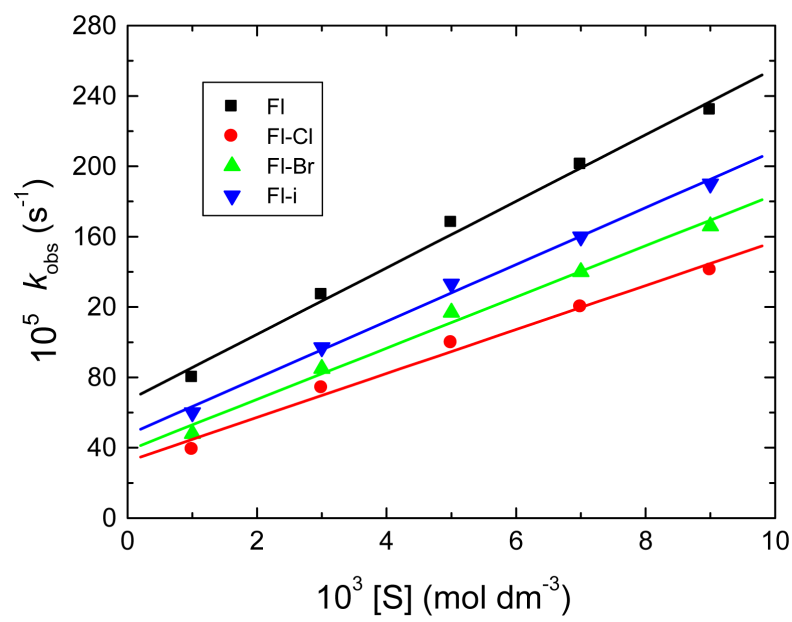

(a)

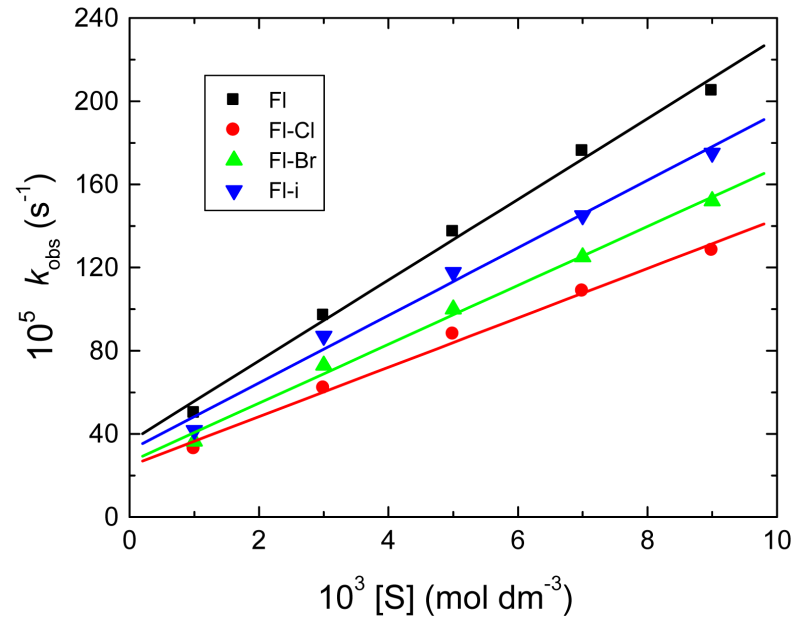

(b)

Figure 3. Plots of the observed first order rate constants $\left(k_{\mathrm{obs}}\right)$ versus substrate concentrations, $[S]$, in the oxidations of fluorene and its derivatives by permanganate ion in: (a) perchloric, and (b) sulfuric acid media. $\left[\mathrm{MnO}_{4}^{-}\right]=4.0 \times 10^{-4},\left[\mathrm{H}^{+}\right]=0.3$ and $I=0.5$ $\mathrm{mol} \cdot \mathrm{dm}^{-3}$ at $25^{\circ} \mathrm{C}$.

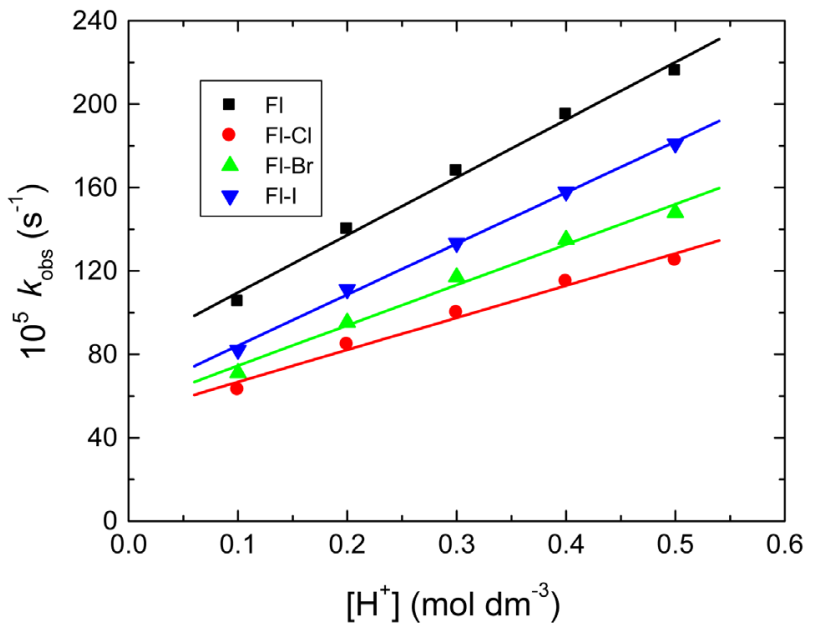

(a) 


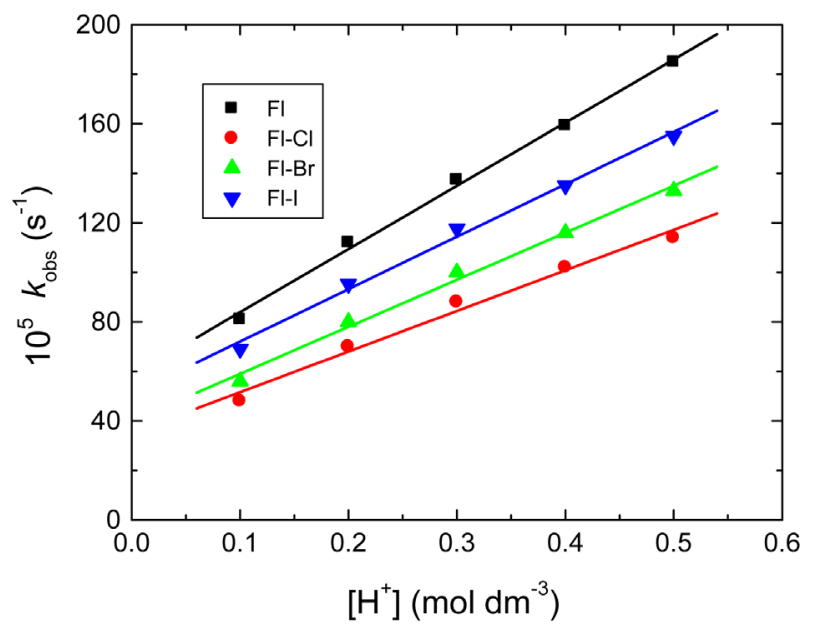

(b)

Figure 4. Plots of the observed first order rate constants $\left(k_{\mathrm{obs}}\right)$ versus acids concentrations in the oxidations of fluorene and its derivatives by permanganate ion in: (a) perchloric, and (b) sulfuric acid media. $\left[\mathrm{MnO}_{4}^{-}\right]=4.0 \times 10^{-4}$, $[\mathrm{S}]=5.0 \times 10^{-3}$ and $I=0.5 \mathrm{~mol} \cdot \mathrm{dm}^{-3}$ at $25^{\circ} \mathrm{C}$.

the ionic strength of the reactions media was varied $\left(0.5-0.9 \mathrm{~mol} \cdot \mathrm{dm}^{-3}\right)$ using sodium perchlorate in perchloric acid and sodium sulfate in sulfuric acid medium. The results listed in Table 1 indicated that variation of ionic strength had no significant effect on the oxidation rates.

\subsection{Effect of Temperature}

To calculate the activation parameters, the observed rate constants were measured at four temperatures, namely 288, 298, 308 and $318 \mathrm{~K}$, at fixed other variables. The observed rate constants were found to increase with raising temperature and the activation parameters of the second order rate constants, $k_{2},\left(k_{2}\right.$ $\left.=k_{\mathrm{obs}} /[\mathrm{S}]\right)$ were evaluated using Arrhenius and Eyring plots (Table 2).

\subsection{Polymerization Study}

Known quantities of acrylonitrile monomer were added to the reactions mixtures in both acidic media and were kept in an inert atmosphere for about 6 hours. When the reactions mixtures were diluted with methanol, progressive white precipitates were formed suggesting intervention of free radicals during these reactions.

\subsection{Reaction Mechanism}

It was reported [33] [34] that permanganate ion in acidic medium combines with $\mathrm{H}^{+}$ion to form a more stronger oxidant called permanganic acid as illustrated by the first step in Scheme 1. This was supported by increasing oxidation rates with increasing acid concentration. On the other hand, many investigators [17]-[24] reported that, most oxidation reactions using permanganate oxidant proceed through formation of intermediate complexes between substrate and 


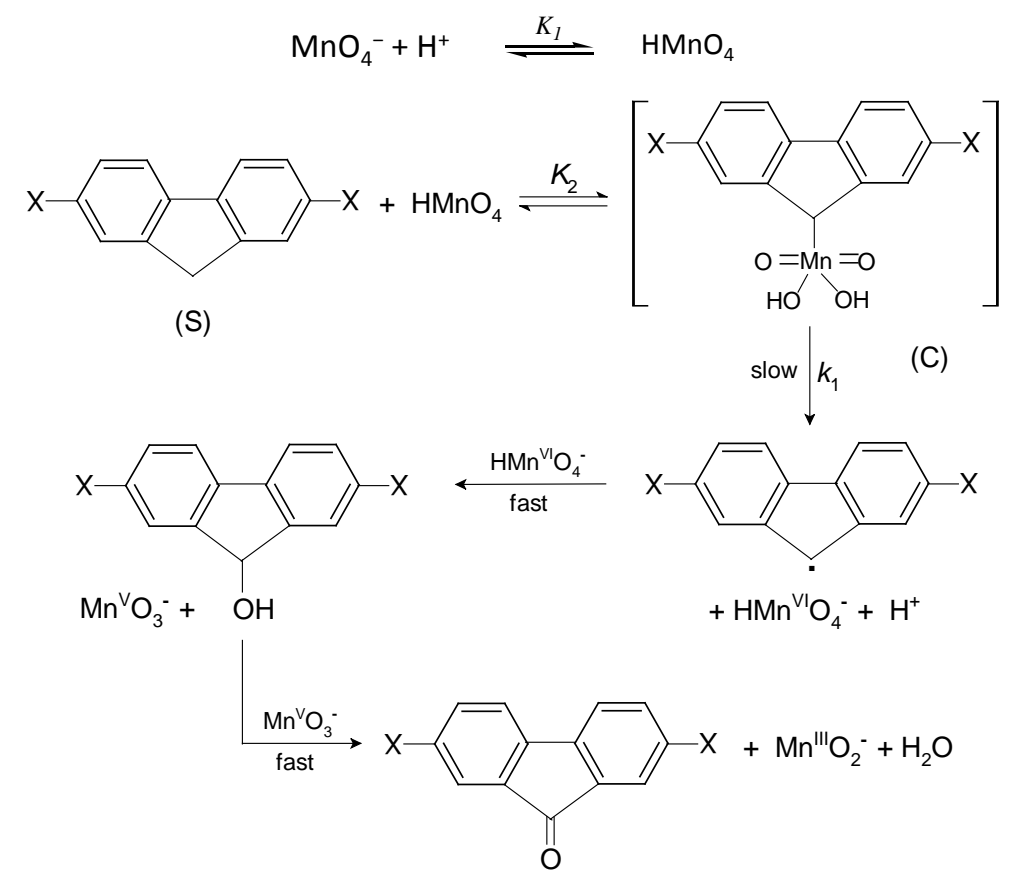

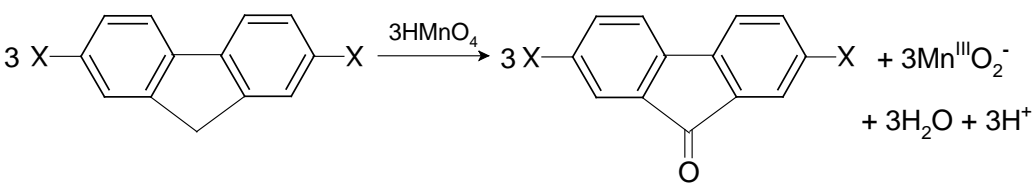

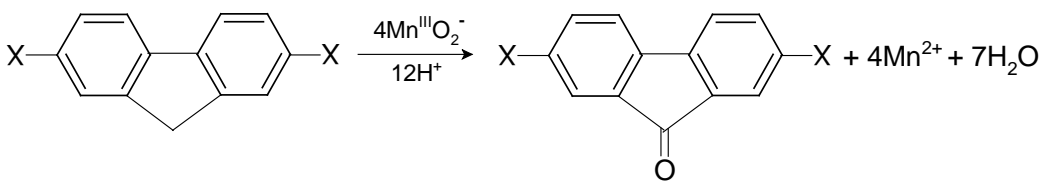

Scheme 1. Mechanism of oxidations of fluorenes by permanganate ion in acid media.

Table 2. Activation parameters of the second order rate constant, $k_{2}$, in the oxidations of fluorene and its derivatives by permanganate ion in perchloric and sulfuric acids media. $\left[\mathrm{MnO}_{4}^{-}\right]=4.0 \times 10^{-4},[\mathrm{~S}]=5.0 \times 10^{-3},\left[\mathrm{H}^{+}\right]=0.3$ and $I=0.5 \mathrm{~mol} \cdot \mathrm{dm}^{-3}$.

\begin{tabular}{cccccc}
\hline Acid & Substrate & $\Delta S^{\ddagger}, \mathrm{J} \cdot \mathrm{mol}^{-1} \mathrm{~K}^{-1}$ & $\Delta H^{\ddagger}, \mathrm{kJ} \cdot \mathrm{mol}^{-1}$ & $\Delta G^{\neq}{ }_{298}, \mathrm{~kJ} \cdot \mathrm{mol}^{-1}$ & $E_{\mathrm{a}}^{\neq}, \mathrm{kJ} \cdot \mathrm{mol}^{-1}$ \\
\hline \multirow{4}{*}{ Perchloric } & Fl & -123.22 & 30.01 & 66.73 & 28.61 \\
& Fl-Cl & -133.35 & 26.03 & 65.79 & 26.33 \\
& Fl-Br & -149.01 & 29.51 & 73.91 & 29.52 \\
& Fl-I & -113.34 & 31.47 & 65.25 & 29.92 \\
& Fl & -148.41 & 26.55 & 70.77 & 36.72 \\
& Fl-Cl & -131.07 & 23.33 & 62.39 & 33.50 \\
& Fl-Br & -134.27 & 25.19 & 65.20 & 37.36 \\
& Fl-I & -157.81 & 24.29 & 71.32 & 39.07 \\
\hline
\end{tabular}

Experimental error $\pm 4 \%$. 
oxidant. This was also evidenced [34] by linear plots of $1 / k_{\mathrm{obs}}$ and $1 /[\mathrm{S}]$ as shown in Figure 5. The observed insignificant influence of the ionic strength on the oxidations rates indicated that the reactions were between two neutral molecules [35] [36] [37], i.e. between fluorene derivative and acid permanganate.

In the light of the above aspects, the following reactions mechanism, illustrated in Scheme 1, can be suggested. The mechanism involves reaction of permanganic acid oxidant with fluorene derivative to form a complex (C) and the later decomposes to yield manganate (VI) and fluorene free radical. The free radical is attacked by $\mathrm{Mn}(\mathrm{VI})$ forming the secondary alcohol (fluorenol) as an intermediate product and manganese (V) intermediate. In a further fast step, $\mathrm{Mn}(\mathrm{V})$ reacts with the intermediate product fluorenol to give the ketone (fluorenone) as the final oxidation product and an intermediate Mn (III) species. This step is followed by other fast steps including reactions of fluorene derivatives with acid permanganate species to form also fluorenone and Mn (III) spe-

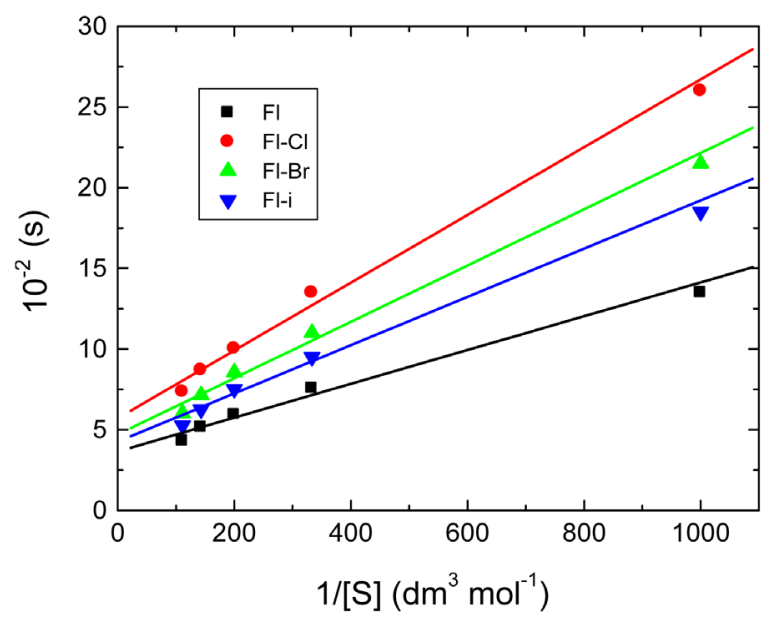

(a)

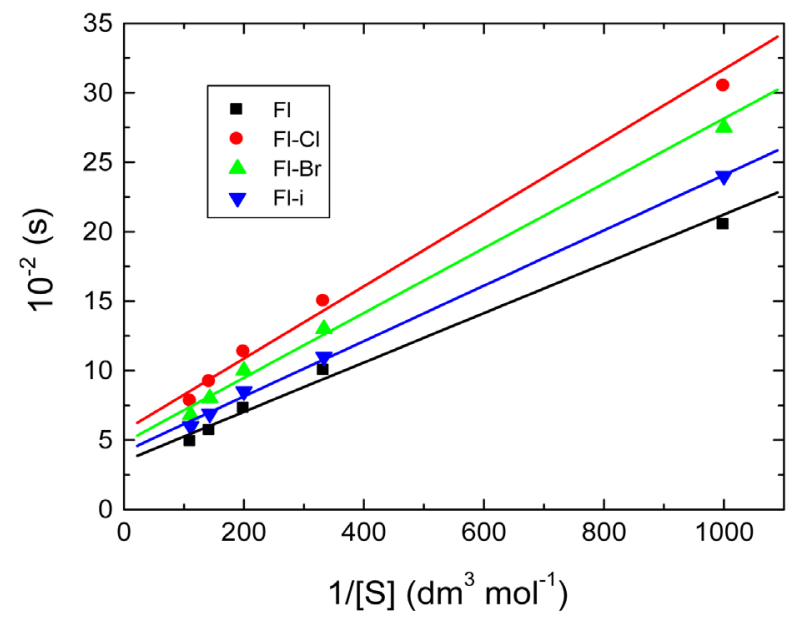

(b)

Figure 5. Verification of equation (4) for the oxidations of fluorene and its derivatives by permanganate ion in: (a) perchloric, and (b) sulfuric acid media. $\left[\mathrm{MnO}_{4}^{-}\right]=4.0 \times 10^{-4}$, $\left[\mathrm{H}^{+}\right]=0.3$ and $I=0.5 \mathrm{~mol} \cdot \mathrm{dm}^{-3}$. 
cies. The last step is the attack of $\mathrm{Mn}$ (III) species on another fluorene molecule to give fluorenone and $\mathrm{Mn}(\mathrm{II})$, satisfying the observed stoichiometry.

Owing to the suggested mechanism, rate of oxidation reaction can be expressed by the following rate law:

$$
\text { Rate }=\frac{-\mathrm{d}\left[\mathrm{MnO}_{4}^{-}\right]}{\mathrm{d} t}=k_{1}[\mathrm{C}]
$$

The relationship between the oxidation rate and the oxidant, substrate and hydrogen ion concentrations is deduced (See Appendix A) to give the following equation:

$$
\text { Rate }=\frac{k_{1} K_{1} K_{2}\left[\mathrm{MnO}_{4}^{-}\right][\mathrm{S}]\left[\mathrm{H}^{+}\right]}{1+K_{1}\left[\mathrm{H}^{+}\right]+K_{1} K_{2}[\mathrm{~S}]\left[\mathrm{H}^{+}\right]}
$$

Under pseudo-first order condition,

$$
\text { Rate }=\frac{-\mathrm{d}\left[\mathrm{MnO}_{4}^{-}\right]}{\mathrm{d} t}=k_{\mathrm{obs}}\left[\mathrm{MnO}_{4}^{-}\right]
$$

From Equations (2) and (3),

$$
\begin{gathered}
\frac{1}{k_{\text {obs }}}=\left(\frac{1+K_{1}\left[\mathrm{H}^{+}\right]}{k_{1} K_{1} K_{2}\left[\mathrm{H}^{+}\right]}\right) \frac{1}{[\mathrm{~S}]}+\frac{1}{k_{1}} \\
\frac{1}{k_{\mathrm{obs}}}=\left(\frac{1}{k_{1} K_{1} K_{2}[\mathrm{~S}]}\right) \frac{1}{\left[\mathrm{H}^{+}\right]}+\left(\frac{1}{k_{1} K_{2}[\mathrm{~S}]}+\frac{1}{k_{1}}\right)
\end{gathered}
$$

Regarding to Equations (4) and (5), plots of $1 / k_{o b s}$ versus $1 /[\mathrm{S}]$ at constant $\left[\mathrm{H}^{+}\right]$and $1 / k_{\mathrm{obs}}$ versus $1 /\left[\mathrm{H}^{+}\right]$at constant $[\mathrm{S}]$ should be linear with positive intercepts on the $1 / k_{\text {obs }}$ axes as were obtained, Figure 5 and Figure 6 , respectively. The slopes and intercepts of such plots lead to calculation of the values of $k_{1}, K_{1}$

\begin{tabular}{|c|c|c|c|c|}
\hline \multirow{2}{*}{ Acid } & \multirow{2}{*}{ Substrate } & \multicolumn{3}{|c|}{ Constant } \\
\hline & & $10^{3} k_{1}, \mathrm{~s}^{-1}$ & $10^{2} K_{1}, \mathrm{dm}^{3} \cdot \mathrm{mol}^{-1}$ & $10^{-3} K_{2}, \mathrm{dm}^{3} \cdot \mathrm{mol}^{-1}$ \\
\hline \multirow{4}{*}{ Pechloric } & $\mathrm{Fl}$ & 2.51 & 29.41 & 5.24 \\
\hline & $\mathrm{Fl}-\mathrm{Cl}$ & 1.80 & 28.80 & 3.26 \\
\hline & $\mathrm{Fl}-\mathrm{Br}$ & 2.12 & 28.32 & 3.31 \\
\hline & Fl-I & 2.43 & 29.53 & 3.18 \\
\hline \multirow{4}{*}{ Sulfuric } & Fl & 2.41 & 28.90 & 4.90 \\
\hline & $\mathrm{Fl}-\mathrm{Cl}$ & 1.73 & 27.61 & 3.15 \\
\hline & $\mathrm{Fl}-\mathrm{Br}$ & 2.21 & 28.84 & 3.10 \\
\hline & Fl-I & 2.34 & 28.53 & 3.34 \\
\hline
\end{tabular}
and $K_{2}$ (Table 3).

Table 3. Values of $k_{1}, K_{1}$ and $K_{2}$ in the oxidations of fluorene and its derivatives by permanganate ion in perchloric and sulfuric acid media. $\left[\mathrm{MnO}_{4}^{-}\right]=4.0 \times 10^{-4},[\mathrm{~S}]=5.0 \times$ $10^{-3},\left[\mathrm{H}^{+}\right]=0.3$ and $I=0.5 \mathrm{~mol} \cdot \mathrm{dm}^{-3}$. 


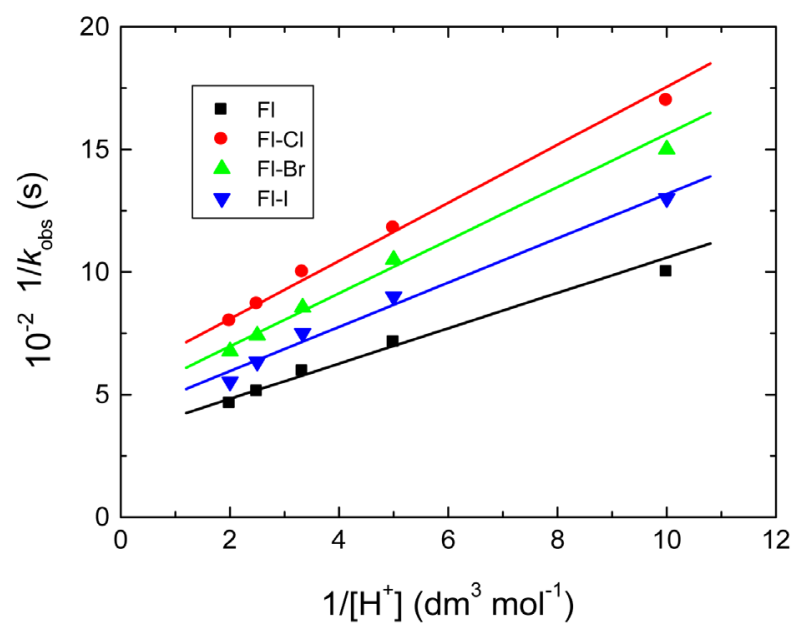

(a)

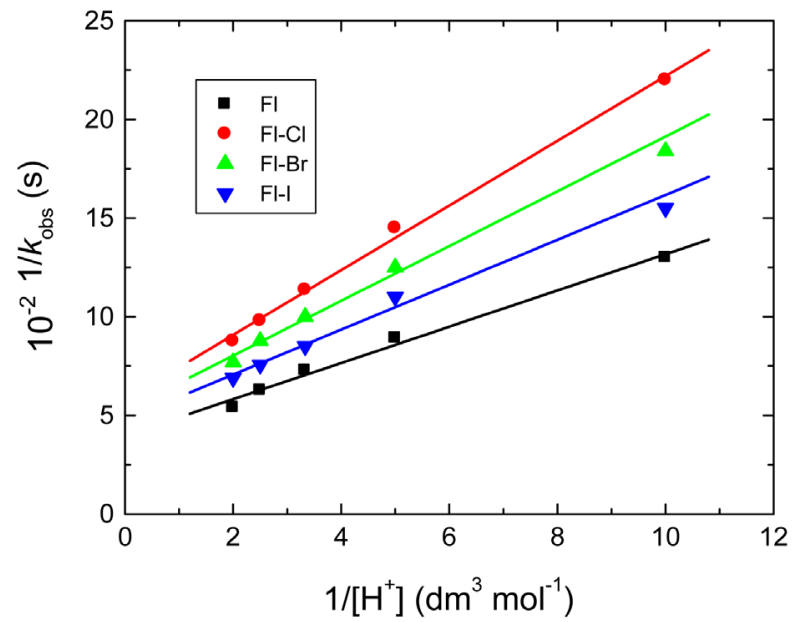

(b)

Figure 6. Verification of equation (5) for the oxidations of fluorene and its derivatives by permanganate ion in: (a) perchloric, and (b) sulfuric acid media. $\left[\mathrm{MnO}_{4}^{-}\right]=4.0 \times 10^{-4}$, $[\mathrm{S}]=5.0 \times 10^{-3}$ and $I=0.5 \mathrm{~mol} \cdot \mathrm{dm}^{-3}$.

On the other hand, the negative values of entropy of activation $\left(\Delta S^{*}\right)$ listed in Table 2 supports formation of compacted intermediate complexes [38]. The positive values of both enthalpy of activation $\left(\Delta H^{\ddagger}\right)$ and free energy of activation $\left(\Delta G^{\star}\right)$ indicates endothermic intermediate complexes and their non-spontaneities, respectively.

\section{Conclusion}

Oxidations of fluorene derivatives by potassium permanganate in acidic medialed to formation of the corresponding ketones (9H-fluorenone derivatives) and the oxidations rate was: $\mathrm{Fl}>\mathrm{Fl}-\mathrm{I}>\mathrm{Fl}-\mathrm{Br}>\mathrm{Fl}-\mathrm{Cl}$. Reaction constants as well as activation parameters were evaluated.

\section{References}

[1] Thormann, T., Rogojerov, M., Jordanov, B. and Thulstrup, E.W. (1999) Vibrational 
Polarization Spectroscopy of Fluorene: Alignment in Stretched Polymers and Nematic Liquid Crystals. Journal of Molecular Structure, 509, 93-99.

[2] Environmental Contaminants Encyclopedia Fluorene Entry July 1, 1997.

[3] Li, X., Lü, H., Wang, S., Guo, J. and Li, J. (2011) Sensitizers of Dye-Sensitized Solar Cells. Progress in Chemistry, 23, 569-588.

[4] Ma, Z., Ding, J., Cheng, Y., Xie, Z., Wang, L., Jing, X. and Wang, F. (2011) Synthesis and Characterization of Red Light-Emitting Electrophosphorescent Polymers with Different Triplet Energy Main Chain. Polymer, 52, 2189-2197.

[5] Wang, H.Y., Qian, M.Q., Lin, K.H., Peng, B., Huang, W., Liu, F. and Wei, W. (2012) Stable and Good Color Purity White Light-Emitting Devices Based on Random Fluorene/Spiro Fluorene Copolymers Doped with Iridium Complex. Journal of Polymer Science B, 50, 180-188. https://doi.org/10.1002/polb.22391

[6] Yang, X.H., Wu, F.I., Neher, D., Chien, C.H. and Shu, C.F. (2008) PolyfluoreneBased Semi-Conductors Combined with Various Periodic Table Elements for Organic Electronics. Chemistry of Materials, 20, 1629-1635. https://doi.org/10.1021/cm702789c

[7] Kucherak, O.A., Didier, P., Mély, Y. and Klymchenko, A.S. (2010) Fluorene Analogues of Prodan with Superior Fluorescence Brightness and Solvatochromism. Journal of Physical Chemistry Letters, 1, 616-620. https://doi.org/10.1021/jz9003685

[8] Cheng, Y.J., Yang, S.H. and Hsu, C.S. (2009) Synthesis of Conjugated Polymers for Organic Solar Cell Applications. Chemical Review, 109, 5868-5923.

https://doi.org/10.1021/cr900182s

[9] Xing, X., Zhang, L., Liu, R., Li, S., Qu, B. and Chen, Z. (2012) A Deep-Blue Emitter with Electron Transporting Property to Improve Charge Balance for Organic LightEmitting Device. ACS Applications Materials Interface, 4, 2877-2883. https://doi.org/10.1021/am300685b

[10] Pina, J., Elo, J.S.S., Egkert, A. and Scherf, U. (2015) Unusual Photophysical Properties of Conjugated, Alternating Indigo-Fluorene Copolymers. Journal of Materials Chemistry $A, 3$, 6373-6381. https://doi.org/10.1039/C4TA06272H

[11] Ahmed, S.A., Abdel-Wahab, A.A. and Dürr, H. (2003) Photochromic NitrogenContaining Compounds. In: Horspool, W.M. and Lenci, F., Eds., CRC Handbook of Organic Photochemistry and Photobiology, CRC Press, New York, 2nd Edition, Chapter 96, 1.

[12] Ahmed, S.A., Hartmann, T. and Dürr, H. (2008) Photochromism of Dihydroindolizines: Part VIII. First Holographic Image Recording Based on Di- \& Tetrahydroindolizines Photochromes. Journal of Photochemistry and Photobiology, 200, 50-56.

[13] Ahmed, S.A. and Pozzo, J.L. (2008) Photochromism of Dihydroindolizines Part IX. First Attempts towards Efficient Self-Assembling Organogelators Based on Photochromicdihy Droindolizines and N-Acyl-I, $\omega$-Amino Acid Units. Journal of Photochemistry and Photobiology, 200, 57-67.

[14] Stewart, R. (1965) Oxidation in Organic Chemistry, Part A. Academic Press, New York.

[15] Jose, T.P., Nandibewoor, S.T. and Tuwar, S.M. (2005) Mechanism of Oxidation of L-Histidine by Heptavalent Manganese in Alkaline Medium. E-Journal of Chemistry, 2, 75-85. https://doi.org/10.1155/2005/206147

[16] Fawzy, A., Ashour, S.S. and Musleh, M.A. (2014) Base-Catalyzed Oxidation of L-Asparagine by Alkaline Permanganate and the Effect of Alkali-Metal Ion Catalysts: Kinetics and Mechanistic Approach. Reaction, Kinetics, Mechanism and Catalysis, 111, 443-460. https://doi.org/10.1007/s11144-014-0679-1 
[17] Fawzy, A. and Shaaban, M.R. (2014) Kinetic and Mechanistic Investigations on the Oxidation of N'-Heteroaryl Unsymmetrical Formamidines by Permanganate in Aqueous Alkaline Medium. Transition Metal Chemistry, 39, 379-386. https://doi.org/10.1007/s11243-014-9811-3

[18] Fawzy, A., Zaafarany, I.A., Alfahemi, J. and Tirkistani, F.A. (2015) Base-Catalyzed Oxidation of Aminotriazole Derivative by Permanganate Ion in Aqueous Alkaline Medium: AKinetic Study. Internationa Journal of Innovative Research in Science and Engineering Technology, 4, 6802-6814. https://doi.org/10.15680/IJIRSET.2015.0408014

[19] Asghar, B.H. and Fawzy, A. (2016) Kinetic, Mechanistic, and Spectroscopic Studies of Permanganate Oxidation of Azinylformamidines in Acidic Medium, with Autocatalytic Behavior of Manganese (II). Journal of Saudi Chemical Society, 20, 561569.

[20] Fawzy, A., Ashour, S.S. and Musleh, M.A. (2014) Kinetics and Mechanism of Oxidation of L-Histidine by Permanganate Ions in Sulfuric Acid Medium. International Journal of Chemical Kinetics, 46, 370-381. https://doi.org/10.1002/kin.20857

[21] Ahmed, G.A., Fawzy, A. and Hassan, R.M. (2007) Spectrophotometric Evidence for the Formation of Short-Lived Hypomanganate (V) and Manganate (VI) Transient Species during the Oxidation of $K$-Carrageenan by Alkaline Permanganate. Carbohydrate Research, 342, 1382-1386.

[22] Zaafarany, I.A., Fawzy, A., Ahmed, G.A., Ibrahim, S.A., Hassan, R.M. and Takagi, H.D. (2010) Further Evidence for Detection of Short-Lived Transient Hypomanganate (V) and Manganate (VI) Intermediates during Oxidation of Some Sulfated Polysaccharides by lkaline Permanganate Using Conventional Spectrophotometeric Techniques. Carbohydrate Research, 345, 1588-1593.

[23] Hassan, R.M., Fawzy, A., Alarifi, A., Ahmed, G.A., Zaafarany, I.A. and Takagi, H.D. (2011) Base-Catalyzed Oxidation of Some Sulfated Macromolecules: Kinetics and Mechanism of Formation of Intermediate Complexes of Short-Lived Manganate (VI) and/or Hypomanganate (V) during Oxidation of Iota- and Lambda-Carrageenan Polysaccharides by Alkaline Permanganate. Journal of Molecular Catalysis $A, 335,38-45$.

[24] Hassan, R.M., Dahy, A., Ibrahim, S., Zaafarany, I.A. and Fawzy, A. (2012) Oxidation of Some Macromolecules. Kinetics and Mechanism of Oxidation of Methyl Cellulose Polysaccharide by Permanganate Ion in Acid Perchlorate Solutions. Industrial and Engineering Chemical Research, 51, 5424-5432.

https://doi.org/10.1021/ie200646p

[25] Gardner, K.A., Kuehnert, L.L. and Mayer, J.M. (1997) Hydrogen Atom Abstraction by Permanganate: Oxidations of Arylalkanes in Organic Solvents. Inorganic Chemistry, 36, 2069-2078. https://doi.org/10.1021/ic961297y

[26] Perez-Benito, J.F. (2011) Permanganate Oxidation of $\alpha$-Amino Acids: Kinetic Correlations for the Nonautocatalytic and Autocatalytic Reaction Pathways. Journal of Physical Chemistry, 115, 9876-9885. https://doi.org/10.1021/jp2043174

[27] Babatunde, O.A. (2008) A Study of the Kinetics and Mechanism of Oxidation LAscorbic Acid by Permanganate Ion in Acidic Medium. World Journal of Chemistry, 3, 27-31.

[28] Day, M.C. and Selbin, J. (1985) Theoretical Inorganic Chemistry. Reinhold Publishing Corporation, New York, 344.

[29] Ahmed, S.A. (2004) Photochromism of Dihydroindolizines. III [1]: Synthesis and Photochromic Behavior of Novel Photochromic Dihydroindolizines Incorporating A Cholesterol Moiety. Monatschef de Chemie, 135, 1173-1181. 
[30] Ahmed, S.A., Khairou, K.S., Asghar, B.H., Muathen, H.A., Nahas, N.M.A. and Al Shreef, H.F. (2014) Photochromism of Tetrahydroindolizines. Part XIV: Synthesis of Cis-Fixed Conjugated Photochromic Pyridazinopyrrolo[1,2-b]Isoquinolines Incorporating Carbon-Rich Linkers. Tetrahedron Letters, 55, 2190-2197.

[31] Vogel, I.A. (1978) A Text Book of Quantitative Inorganic Analysis. 4th Edition, ELBS and Longman, New York, 352.

[32] Zahedi, M. and Bahrami, H. (2004) Kinetic and Mechanism of Autocatalytic Oxidation of L-Asperagine in Moderately Concentrated Sulphuric Acid Medium. Kinetics and Catalysis, 45, 351-358. https://doi.org/10.1023/B:KICA.0000032168.35401.3e

[33] Hosahalli, R.V., Savanur, A.P., Nandibewoor, S.T. and Chimatadar, S.A. (2012) Kinetics and Mechanism of the Autocatalyzed Oxidation of Theophylline by Permanganate in Aqueous Perchloric Acid Medium. Journal of Solution Chemistry, 41, 567-580. https://doi.org/10.1007/s10953-012-9819-2

[34] Michaelis, L. and Menten, M.L. (1913) The Kinetics of Invertase Action. Biochemistry $Z, 49,333-369$.

[35] Frost, A.A. and Person, R.G. (1973) Kinetics and Mechanism. Wiley Eastern, New Delhi, 147.

[36] Amis, E.S. (1966) Solvent Effect on Reaction Rates and Mechanism. Academic Press, New York, 28.

[37] Laidler, K. (1965) Chemical Kinetics. McGraw-Hill, New York, 123.

[38] Weissberger, A. (1974) Investigation of Rates and Mechanism of Reactions in Techniques of Chemistry. John Wiley \& Sons, New York, 421. 
Appendix A. Derivation of the Rate-Law Expression

$$
\begin{gathered}
\text { Rate }=\frac{-\mathrm{d}\left[\mathrm{MnO}_{4}^{-}\right]}{\mathrm{d} t}=k_{1}[\mathrm{C}] \\
K_{1}=\frac{\left[\mathrm{HMnO}_{4}\right]}{\left[\mathrm{MnO}_{4}^{-}\right]\left[\mathrm{H}^{+}\right]}, \quad\left[\mathrm{HMnO}_{4}\right]=K_{1}\left[\mathrm{MnO}_{4}^{-}\right]\left[\mathrm{H}^{+}\right] \\
K_{2}=\frac{[\mathrm{C}]}{[\mathrm{S}]\left[\mathrm{HMnO}_{4}\right]}, \quad[\mathrm{C}]=K_{2}[\mathrm{~S}]\left[\mathrm{HMnO}_{4}\right]=K_{1} K_{2}[\mathrm{~S}]\left[\mathrm{MnO}_{4}^{-}\right]\left[\mathrm{H}^{+}\right]
\end{gathered}
$$

From Equations (A1) and (A3),

$$
\text { Rate }=k_{1} K_{1} K_{2}[\mathrm{~S}]\left[\mathrm{MnO}_{4}^{-}\right]\left[\mathrm{H}^{+}\right]
$$

The total concentration of $\mathrm{MnO}_{4}^{-}$is given by (where "T" and "F" stand for total and free),

$$
\begin{gathered}
{\left[\mathrm{MnO}_{4}^{-}\right]_{\mathrm{T}}=\left[\mathrm{MnO}_{4}^{-}\right]_{\mathrm{F}}+\left[\mathrm{HMnO}_{4}\right]+[\mathrm{C}]} \\
{\left[\mathrm{MnO}_{4}^{-}\right]_{\mathrm{T}}=\left[\mathrm{MnO}_{4}^{-}\right]_{\mathrm{F}}+K_{1}\left[\mathrm{MnO}_{4}^{-}\right]_{\mathrm{F}}\left[\mathrm{H}^{+}\right]+K_{1} K_{2}\left[\mathrm{MnO}_{4}^{-}\right]_{\mathrm{F}}[\mathrm{S}]\left[\mathrm{H}^{+}\right]} \\
{\left[\mathrm{MnO}_{4}^{-}\right]_{\mathrm{F}}=\frac{\left[\mathrm{MnO}_{4}^{-}\right]_{\mathrm{T}}}{1+K_{1}\left[\mathrm{H}^{+}\right]+K_{1} K_{2}[\mathrm{~S}]\left[\mathrm{H}^{+}\right]}}
\end{gathered}
$$

Because of $\left[\mathrm{H}^{+}\right]$was high,

$$
\left[\mathrm{H}^{+}\right]_{\mathrm{T}}=\left[\mathrm{H}^{+}\right]_{\mathrm{F}}
$$

Similarly

$$
[\mathrm{S}]_{\mathrm{T}}=[\mathrm{S}]_{\mathrm{F}}
$$

Substituting Equations (A7), (A8) and (A9) into Equation (A4) (and omitting " $T$ " and "F" subscripts) gives:

$$
\text { Rate }=\frac{k_{1} K_{1} K_{2}\left[\mathrm{MnO}_{4}^{-}\right][\mathrm{S}]\left[\mathrm{H}^{+}\right]}{1+K_{1}\left[\mathrm{H}^{+}\right]+K_{1} K_{2}[\mathrm{~S}]\left[\mathrm{H}^{+}\right]}
$$

Under pseudo-first order condition,

$$
\text { Rate }=\frac{-\mathrm{d}\left[\mathrm{MnO}_{4}^{-}\right]}{\mathrm{d} t}=k_{\mathrm{obs}}\left[\mathrm{MnO}_{4}^{-}\right]
$$

From Equations (A10) and (A11),

$$
k_{\text {obs }}=\frac{k_{1} K_{1} K_{2}[\mathrm{~S}]\left[\mathrm{H}^{+}\right]}{1+K_{1}\left[\mathrm{H}^{+}\right]+K_{1} K_{2}[\mathrm{~S}]\left[\mathrm{H}^{+}\right]}
$$

and with rearrangement of Equation (A12),

$$
\begin{gathered}
\frac{1}{k_{o b s}}=\left(\frac{1+K_{1}\left[\mathrm{H}^{+}\right]}{k_{1} K_{1} K_{2}\left[\mathrm{H}^{+}\right]}\right) \frac{1}{[\mathrm{~S}]}+\frac{1}{k_{1}} \\
\frac{1}{k_{\text {obs }}}=\left(\frac{1}{k_{1} K_{1} K_{2}[\mathrm{~S}]}\right) \frac{1}{\left[\mathrm{H}^{+}\right]}+\left(\frac{1}{k_{1} K_{2}[\mathrm{~S}]}+\frac{1}{k_{1}}\right)
\end{gathered}
$$


Submit or recommend next manuscript to SCIRP and we will provide best service for you:

Accepting pre-submission inquiries through Email, Facebook, LinkedIn, Twitter, etc. A wide selection of journals (inclusive of 9 subjects, more than 200 journals)

Providing 24-hour high-quality service

User-friendly online submission system

Fair and swift peer-review system

Efficient typesetting and proofreading procedure

Display of the result of downloads and visits, as well as the number of cited articles Maximum dissemination of your research work

Submit your manuscript at: http://papersubmission.scirp.org/

Or contact ojpc@scirp.org 